\title{
Teoretická východiska mediální výchovy jako determinant mediálněpedagogické praxe
}

\author{
Petr Valenta \\ Univerzita Karlova, Filozofická fakulta, Katedra pedagogiky
}

Redakci zasláno 5. 2. 2017 / upravená verze obdržena 19. 8. 2017 /

k uveřejnění přijato 4. 9. 2017

\begin{abstract}
Abstrakt: Cílem teoretické studie je nastínit strukturální problémy mediální výchovy vyplývající z její teoretické závislosti na mediálních studiích a sociálněvědním paradigmatu výzkumu mediálních účinků. V úvodu je mediální výchova představena $\mathrm{v}$ teoretickém poli mediálních studií. Je argumentováno, že mediální výchova nedisponuje vlastní teorií, nýbrž odvozuje poznatkový aparát, didaktické cíle, obsah a metody od dominantních konceptů médií generovaných v oboru mediální studia. Strukturálním elementem mediálněpedagogické praxe je přitom koncept účinků médií a přístup k jejich zkoumání. Převaha sociálněvědního přístupu ve výzkumu mediálních účinků vede k formování konceptu mediálních účinků, které lze pozorovat, popsat a zobecnit. Tento přístup však neumožňuje plně uchopit problematiku médií v jejich sociálním a kulturním kontextu a vede k ustavení mediální výchovy, která je protekcionistická, normativní a objektivistická. Závěrem je pak nabídnuta alternativa v podobě kritického přístupu umožňujícího strukturovat mediální výchovu jako autonomní výzkumné a pedagogické pole. Mediální výchova může nabírat řadu různých podob na základě toho, jaké teoretické koncepty médií považuje za referenční. Dominantní model mediální výchovy, orientovaný na sociálněvědní paradigma výzkumu mediálních účinků, může být obohacen o další perspektivy, které umožní komplexnější porozumění médiím v jejich sociálním kontextu a povedou ke kritické reflexi nejen mediálních, ale obecně sociálních a mocenských praxí. Takové pojetí mediální výchovy bude efektivněji přispívat k rozvoji kriticky smýšlejícího aktéra mediální komunikace. Je nezbytné znovu promyslet teoretická východiska a cíle mediální výchovy a vyvázat ji z teoretické závislosti na konceptu mediálních účinků formulovaného $\mathrm{v}$ sociálněvědním paradigmatu mediálních studií. Integrace interpretativních a kritických přístupů podpoří lépe rozvoj kritické mediální gramotnosti a umožní mediální výchově vytvářet vlastní poznatkový aparát a organizovat autonomně vlastní pedagogickou praxi.
\end{abstract}

Klíčová slova: mediální výchova, mediální studia, sociálněvědní paradigma, mediální účinky, protekcionismus, normativnost, objektivismus, kritická mediální gramotnost 
Současná podoba mediální výchovy je výsledkem vzájemného působení řady faktorů, z nichž nejvýznamnější tvoří dynamicky se rozvíjející oblast komunikačních technologií a její teoretická reflexe v sociálních vědách. Mediální výchova reaguje na proměňující se mediální prostředí organizací pedagogických intervencí ${ }^{1}$, které mají jednotlivce na koexistenci s médii adaptovat. Konkrétní cíle, formy a výstupy těchto intervencí vyplývají mimo jiné z toho, jak jsou média, a především jejich vliv na člověka a společnost, teoretizována v těch oborech, které média chápou jako vlastní objekt zkoumání, tedy zejména v mediálních studiích.

Empirická zkušenost s médii vede k obecnému přesvědčení, že média mají „značný vliv na veřejné mínění, cítění a jednání" (McGuire, 1986, s. 174) a „výrazný vliv na chování jedince a společnosti, na utváření životního stylu a na kvalitu života vůbec" (RVP ZV, s. 101). Veřejnému i odbornému diskurzu (a také výzkumu médií) od počátku dominuje problematika mediálního působení, resp. mediálních účinků. Představy o mediálních účincích historicky oscilují mezi póly silných a minimálních účinků (viz např. Jirák \& Köpplová, 2003), přičemž příklon $k$ jednomu či druhému výkladu je vždy ovlivněn sociální interpretací nově nastupujícího média a jeho kulturní role (přicházející nejen z řad akademiků, ale také kulturních kritiků, lékařů, pedagogů, politiků či obecně veřejnosti; viz např. Storey, 2008).

O‘Sullivan a kol. (1994) konstatují, že výzkum médií nese obrysy veřejného či politického názoru. $V$ jeho středu stojí otázka účinků médií, tedy vlivu médií na společnost a jednotlivce. S vlivem médií jsou spojovány otázky spotřebitelského chování, poklesu vzdělanosti, poruch stravování, užívání drog, kriminálního jednání nebo chování společnosti v krizových situacích (Perse, 2001; Kline, 2003; Barker \& Petley, 2003). Tato perspektiva ovlivňuje společenskou poptávku po teoretickém výkladu médií, motivuje badatelské aktivity (viz např. Livingstone, 1996), determinuje výzkumné otázky, ovlivňuje design výzkumu a interpretace dat (viz Potter, Cooper, \& Dupagne, 1993, in Valenta, 2016) a stimuluje sociální intervence legislativní, cenzurní nebo pedagogické povahy. Aktuální představy o moci médií tak organizují rozmanitou sociální praxi (akademickou, politickou, pedagogickou...) a zároveň strukturují poznatky, postupy a návody jednání vztahující se k médiím.

V tomto procesu mají specifické postavení sociální vědy (viz Sholle, 1994), především mediální studia. Realita médií tak, jak je pojímána v odborném

Mediálněpedagogickými intervencemi chápeme jakýkoliv typ reakce na skutečné nebo předpokládané působení médií, které se projeví v určité formě mediálněpedagogické praxe. 
vědeckém myšlení ( $\mathrm{a} v$ mediální výchově), je realitou produkovanou diskurzem mediálních studií: ty mají dominantní pozici v produkci, distribuci a kontrole odborného vědění vztahujícího se $\mathrm{k}$ médiím, vymezují charakter vědeckých výpovědí o médiích, tedy to, co je ve vztahu k médiím považováno za pravdivé a vědecky validní (viz Valenta, 2016). Organizují tak určité formy sociálních praxí a vytvářejí ve vztahu k médiím implicitní rámce pro konkrétní jednání. ${ }^{2}$

\section{$1 \quad$ Mediální výchova v diskurzu mediálních studií}

Mediální výchova se, jako pedagogická reakce na určité představy o médiích, resp. jejich účincích (viz Mihailidis, 2008, s. 193), a jako výchovně-vzdělávací praxe pevně etablovaná $\mathrm{v}$ institucionalizovaném systému vzdělávání, musí opírat o soubor pokud možno platných, vědecky validovaných tezí a faktů. Výzkumy (Anderson, 1980; Piette \& Giroux, 1996) přitom ukazují na absenci vlastního poznatkového aparátu mediální výchovy a významnou orientovanost na mediální studia:

Jsme nuceni pochybovat, zda může být mediální výchova aktuálně vnímána jako autonomní pole vybavené svým vlastním rozlišujícím teoretickým rámcem. Spíše se přikláníme $\mathrm{k}$ tomu, že mediální výchova je jako (vědecké) pole umístěna uvnitř širšího rámce teoretických pozic (oboru) masové komunikace. Jak vidíme, mediální výchova neuspěla v rozvoji autonomního teoretického rámce, ze kterého by se mohla koherentně rozvíjet její praxe. (Piette \& Giroux, 1996, s. 126)

Mezi mediální výchovou a mediálními studii tak existuje vztah teoretické, a můžeme dodat také didakticko-metodologické, závislosti. Jinak řečeno, mediální výchova není autonomní disciplínou disponující vlastní teorií. Její cíle, obsah, referenční objekt a sekundárně také techniky a metody jsou odvozeny od dominantních konceptů médií produkovaných diskurzy oboru mediálních studií. Mediální výchova tak „aplikuje poznatky a teorie mediálních studií

2 Je ovšem třeba připustit, že suma společenského vědění o médiích není tvořena pouze v diskurzu akademickém, ale současně také v diskurzu profesním (žurnalistickém, pedagogickém) či veřejném neboli laickém, tedy v diskurzu tvořeném samotnými uživateli médií. Tyto diskurzy se vzájemně ovlivňují a prolínají, dohromady tvoří komplementární diskurzivní formaci (viz Foucault, 2002). Pouze akademický diskurz může ovšem reprezentovat relativní objektivnost poznání, jelikož zakládá své teze na výzkumně ověřených hypotézách, které do jisté míry eliminují subjektivitu jedince (i když nikdy ne zcela). Proto lze říci, že pro všechny ostatní vědní obory zabývající se v určitých kontextech problematikou médií (tedy také pro mediální výchovu) jsou referenčními právě poznatky produkované mediálními studii: ty jsou přejímány, interpretovány, ověřovány, doplňovány atd. 
(a dalších oborů) a výzkumů médií na praktickou průpravu zejména mladých generací" (Jirák, 2006). Teorie, a do jisté míry i praxe, mediální výchovy je tedy dominantně formována mimo pedagogiku samotnou, v mediálních studiích. ${ }^{3}$

\subsection{Př́stupy ke studiu médií}

Teoretická závislost na klíčových konceptech konstituovaných v diskurzech mediálních studií může mít zásadní dopad na obsah, cíle a organizační formy mediální výchovy. ${ }^{4}$ Mediální studia ovšem nejsou tvořena homogenním souborem konsenzuálních teorií, ale integrují různé přístupy lišící se ve způsobu nazírání sociální reality a jejích aktérů (viz Fink \& Gantz, 1996):

1) Sociálněvědní př́ístup chápe společnost atomisticky, jako souhrn izolovaných, na sobě navzájem nezávislých entit. Základní jednotkou pro analýzu společnosti je jednotlivec chápaný jako racionálně jednající bytost. Sociální hodnoty, instituce a procesy jsou odvozené od individuálních zájmů a jednání jednotlivců. Vědění je vytvářeno prostřednictvím sdílených významů, které jsou univerzální a jednotné. Porozumění sociálním jevům je možné skrze jejich prosté pozorování.

2) Interpretativní přístup vnímá společnost holisticky. Realita je taková, jakou ji lidé nazírají. Porozumění realitě je možné pouze tak, že ji budeme nahlížet perspektivou daného člověka. Významy jsou polysémické, vědění je tvořeno subjektivními procesy holistické analýzy. Interpretativní přístup se snaží porozumět významu jedinečných a subjektivních fenoménů. Výzkum se zaměřuje převážně na odhalování individuálních procesů při posuzování významu mediálních sdělení a jejich užívání, cílem je kontextuální vysvětlení zkoumaného jevu.

3) Kritický přístup předpokládá, že všechny sociální jevy a procesy odrážejí určité hodnoty. Veškeré sociální praxe jsou podmíněny ideologií, která je vždy aspektem moci. Ideologie pomáhá konstruovat vědění tím, že selektuje a zdůrazňuje určité aspekty sociální reality. Kritické přístupy vnímají podstatu vědění v kritické reflexi hodnot, které determinují mody myšlení a jsou jimi vyjádřeny. Odhalování ideologické determinace mediálních sdělení je pak předpokladem sociální emancipace a změny.

3 Proto mohou být rozvoj mediální gramotnosti a mediální výchova prezentovány také jako „aplikovaná mediální studia“ (viz MUP Praha, dostupné z http://www.mup.cz/o-univerzite/ katedry/katedra-medialnich-studii/).

4 Podle Foucaulta (2002) diskurz produkuje realitu, $v$ tomto případě realitu mediálněpedagogické praxe projevující se v uvedených didaktických kategoriích. 
V mediálních studiích jsou tedy zahrnuta paradigmata založená z jedné strany na pozitivistickém a behaviorálním výzkumu, z druhé strany pak na kulturální a kritické analýze médií (viz např. Potter, Cooper, \& Dupagne, 1993; Fourie, 2007; Wimmer \& Dominick, 2010). Všechny tyto př́stupy přispěly k ustavení určitých výzkumných modelů studia médií a v různé míře ovlivnily současné formy uvažování o médiích a podoby mediálněpedagogické praxe. Všechny tyto přístupy také určitým způsobem konceptualizují účinky médií.

\section{2 Účinky médií jako strukturní prvek mediálních studií a mediální výchovy}

Podle O’Neila (2011) zaujímá výzkum účinků médií „vysoce vlivnou a dominantní roli v mainstreamových komunikačních studiích". O’Sullivan a kol. (1994) konstatují, že „úzká otázka účinků dominuje a slouží k definování značného objemu [akademické, pozn. aut.] debaty“ (s. 101). „Jeden z hlavních zájmů studia masové komunikace jsou sociální, kulturní a psychologické účinky mediálního obsahu," uvádí Perse (2001, s. 1). McQuail (1999) označuje tradici výzkumu mediálních účinků jako „dominantní paradigma v teorii a výzkumu" mediálních studií (s. 64). Otázka vlivu médií se zdá být pro komunikační studia fundamentální (viz Lowery \& DeFleur, 1995). Také v mediální výchově pracuje většina autorů s předpokladem, že „masová média kontinuálně uplatňují všechny druhy přímých i nepř́imých vlivů na člověka a společnost“ (viz Potter, 2010, s. 681). Účinky médií jsou tak do jisté míry „páteří mediálních studií“ (Nečas \& Trampota, 2008) a také mediální výchovy.

\subsection{Koncept účinků médií jako konstitutivní prvek mediální výchovy}

Vnímání problematiky médií dominantně z perspektivy jejich účinků vede k obecně sdílenému přesvědčení, že média představují „významný faktor primární i sekundární socializace" (Doporučené očekávané výstupy, 2001, s. 69). Toto výchozí přesvědčení poskytuje relevanci určitému typu mediálněpedagogických intervencí a ospravedlňuje obecně roli mediální výchovy v edukaci dětí a mládeže. ${ }^{5}$

K tomu, aby se mediální výchova ustavila jako výchova, tedy jako disciplína usilující o komplexní formování osobnosti člověka z hlediska jeho hodnot, postojů, mínění a kompetencí ve vztahu k médiím, je ovšem nezbytné nejen

Autor se přitom nesnaží zkoumat ani zpochybňovat pravdivost tohoto přesvědčení, usiluje na základě analýzy konceptu mediálních účinků o vyvození možných důsledků pro konstituci mediálněpedagogické praxe v českém modelu mediální výchovy. 
vnímat účinky médií jako reálné, ale navíc také jako reálně či potenciálně problematické, vyžadující zprostředkování, vysvětlení, intervenci. ${ }^{6}$ To následně vytváří tlak na systematizaci konkrétních pedagogických strategií a způsobuje, že média se stávají exkluzivním objektem všeobecného vzdělávání.

Pozornost, která je věnována specifickým účinkům médií, nemá ve školním kurikulu ekvivalent. Zatímco žáci se učí chápat, jak média ovlivňují jejich názory, postoje a myšlení, nejsou podobné reflexi podrobeny ostatní socializační instituce typu rodiny, školy, práva atd. Zatímco žáci si mají od médií vypěstovat „kritický odstup“ (RVP ZV), ve vztahu k rodičům, učiteli, státu toto není vyžadováno. Ustavení mediální výchovy jako jednoho z témat všeobecného vzdělávání (na rozdíl např̀ od výchovy k obecnému kritickému myšlení, která by reflektovala všechny instituce symbolické moci a jejich vliv na formování mínění a postojů žáků) může ukazovat, že média mají v pedagogice jako socializační instituce $v$ jistém smyslu privilegované postavení dané především tím, že jsou v kurikulu vyčleněna ze systémů sociálního působení a konceptualizována jako dominantní formativní síla mimo jejich sociální a institucionální kontext. Jinak řečeno, moc médií je natolik významná, že právě o nich (a ne o jiných socializačních institucích) má smysl se učit.

Představa mocných ${ }^{7}$ médií tak poskytuje klíčový koncept, okolo kterého se konstituuje mediální výchova. Současně do značné míry řeší problém s vymezením "konceptuálního smyslu pole“ oboru (viz Masterman, 1985, s. 16). V oblasti tak široké a komplexní, zahrnující tolik rozmanitých procesů, praktik a výstupů, jako jsou média, může být nesnadné identifikovat skutečnosti a jevy, které se mají stát objektem výuky, mají dát mediální výchově relevanci. Jednoduše řečeno není snadné definovat předmět a obsah mediální výchovy. Tyto obtíže vedou k úsilí vytvořit sjednocující rámec problematiky, který by dával konceptu médií konkrétní smysl a byl tedy formou vhodnou pro aplikaci do praktické pedagogiky. Tímto jednotícím smyslem se opět zdá být předpoklad (mocných a potenciálně nežádoucích) účinků médií, který umožňuje definovat cíle, témata a jednotlivé aktivity mediální výchovy zaměřené primárně na rozvoj těch kompetencí, které by vliv médií na člověka eliminovaly.

6 Pokud by tomu tak nebylo, žáci by se učili vnímat média pouze jako jeden ze zprostředkovatelů reálného obrazu reality a nebyli by vzděláváni v problematice médií jako takových. Jak uvádí Masterman (1985): „Tento pohled na média by nám umožňoval zkoumat pouze různé oblasti zkušeností pokrytých médii [...] namísto médií samotných." (viz Masterman, 1985, s. 18).

7 Autor zde neodkazuje na zjednodušující koncept mocných médií, který dominoval první polovině 20. století. Má na mysli obecně sdílenou sociální definici médií jako společenské instituce disponující mocí, která je historicky kontinuální a která stimuluje výzkum médií i mediálněpedagogické intervence, viz výklad výše. 


\subsection{Kritika výzkumu mediálních účinků}

Ve skutečnosti nicméně nepanuje mezi mediálními teoretiky ohledně vlivu médií a způsobů jeho prokazování konsenzus. Podle McQuaila (1987) je sice „celé studium masové komunikace založeno na předpokladu, že existují účinky médií, přesto se zdá, že právě v této otázce panuje nejméně jistoty a nejméně souhlasu“ (s. 251). ${ }^{8}$ Prokazování účinků médií je problém především metodologický.

Potter, Dupagne a Cooper (1993) uvádějí jako „matku mediálních studií ve smyslu poskytování výzkumných metod, otázek a teorií“ (s. 318) sociologii, resp. sociálněvědní paradigma v mediálních studiích. Z jejich práce vyplývá, že až $70 \%$ výzkumů médií je sociálněvědně orientováno co do účelu (vysvětlit), předmětu (obsah médií a jejich účinky na jednotlivce) a designu výzkumu (kvantitativní, nepravděpodobnostní výběr).

McQuail (1999) konstatuje, že sociálněvědnímu přístupu je vlastní pozitivismus a lineární kauzalismus vytvářející představu přímého a univerzálního vlivu médií, který je možné empiricky prokázat odhalením zobecnitelných vzorců v mediálních obsazích a v lidském chování. Hlavním objektem badatelského zájmu jsou média samotná, jejich vliv je chápán jako daný, vyplývající již z podstaty médií jako instituce sociální komunikace. Člověk je vnímán spíše jako objekt mediálního působení, děti a mládež pak jako potenciální oběti nežádoucích mediálních obsahů (násilných, vulgárních, sexuálně explicitních apod.). ${ }^{9}$

8 Zde uvedená citace je doslovnou citací z druhého vydání anglické verze McQuailova Úvodu do teorie masové komunikace z roku 1987. V originálním znění McQuail uvádí: „The entire study of mass communication is based on the premise that there are effects from the media, yet it seems to be the issue on which there is least certainty and least agreement". V českém překladu stejné knihy (Jirák, 1999) ovšem věta zní takto: „Celé studium masové komunikace je založeno na předpokladu, že média mají významné účinky, a přece bychom našli jen málo shodných názorů na jejich povahu a rozsah“ (s. 359). Je pozoruhodné, že v originální verzi McQuail poukazuje na minimální konsenzus badatelů týkající se mediálních účinků jako takových, kdežto v českém překladu jsou účinky prezentovány jako dané (a dokonce „významné") a odborný nesoulad je vztažen pouze k otázce jejich „povahy“ a „rozsahu“.

9 Taková definice sociálněvědního přístupu může opět svádět ke srovnání s již překonaným pojetím účinků médií 1 . poloviny 20 . století a k jejímu odmítnutí pro irelevanci. Nicméně dle Finka a Ganze (1996) sociálněvědní př́stup obecně pracuje s a priori utvořenými kategoriemi jevů, které se následně snaží výzkumně prokázat nebo vyloučit. To znamená, že postuluje předem určité teze, které teprve ověřuje, a to na základě určitého výchozího přesvědčení, které může být společensky determinováno (viz výše O‘Sullivan, 1994). 
Podle Napoliho (2014) převažuje ve výzkumu médií orientace na individuální reakce jednotlivců na mediální obsahy, tedy na analýzu změn v myšlení, postojích, emočním prožívání a chování u konkrétních respondentů:

Pole (výzkumu, pozn. aut.) mediálních účinků může být charakterizováno silnou mikro-orientací, ve které je jednotkou analýzy typicky individuální uživatel médií, a je zaměřeno na relativně úzkou otázku, zda vystavení určitému mediálnímu sdělení ovlivnilo uživatelovy postoje, přesvědčení, vědění nebo chování. (viz Napoli, 2014, s. 8)

Zjištění získaná analýzou této „mikroúrovně“ je však obtížné generalizovat (srov. dále např. Livingstone, 1996, s. 309), přesto má sociálněvědní přístup tendence vyvozovat z jednání lidí ve specifických situacích obecně platné zákonitosti mediálního působení. Uchyluje se tak často k předčasným závěrům (viz Gauntlett, 1998), aniž by byl schopen komplexněji akcentovat roli individuálních faktorů ovlivňujících reakce člověka na mediální obsahy (vzdělání, zkušenost, postoje a mínění), ale především sociální, politický a ekonomický kontext médií, dialektický vztah mezi médii a sociálními institucemi a formy jejich vzájemného ovlivňování, tvořící „makroúroveň“ zkoumání médií (viz Napoli, 2004; dále např. Williams, 1975; Gauntlett, 1998; Barker \& Petley, 2003). ${ }^{10}$

Představy o účincích médií na člověka jsou tak formulovány na základě jejich extrakce od sociálního kontextu a potlačení individuality př́jemce mediálních sdělení. Podle Gauntletta (1998) přistupuje sociálněvědní paradigma k problematice odzadu: namísto toho, aby se snažilo porozumět sociálním jevům v jejich kontextu, a případně zkoumalo míru vlivu médií na jejich výskyt a formu, nastolí direktivně kauzální vztah k mediálním obsahům a poté se je snaží empiricky prokázat. „Není nic takového jako násilí v médiích, které může mít poškozující nebo přínosný účinek," konstatují Barker a Petley (2001, s. 2) s odkazem na to, že nelze na základě různorodých obsahů médií, vytvářených za různými účely a příjemci různě interpretovaných, usuzovat na konkrétní a univerzální účinek. Změna v osobnosti člověka nebo v sociální dynamice společnosti je spíše než výsledkem náhlého impulsu výsledkem komplexního a složitého procesu, v němž se střetávají různé síly sociální, kulturní i mediální povahy, které mohou působit synergicky, ale také protikladně. Lapidárně to již dř́ve vyjádřili Schramm, Lyle a Parker (1961):

10 Napoli proto navrhuje odlišit mediální účinky od „mediálního dopadu“, jehož problematika přesahuje působení médií na individuálního uživatele a „zahrnuje širší systémové změny na úrovni organizací a institucí" (Napoli, 2014, s. 8). 
Pro určité děti a za určitých okolností určitá televize (ve smyslu televizní obsah, pozn. aut.) může být škodlivá. Pro určité děti za stejných okolností nebo pro stejné děti za jiných okolností může být přínosná. Pro většinu dětí za většiny podmínek není většina televizních obsahů ani primárně škodlivá, ani primárně přínosná. (s. 61)

Tendence vytvořit teoretický rámec popisující proces mediálního působení jako neměnnou strukturu pravidel a zákonitostí tak vede nutně k ignorování určitých aspektů mediální komunikace (sociokulturní dimenze). Výsledky sociálněvědních výzkumů médií jsou tak do jisté míry konstrukty založenými na „bázi reduktivních předpokladů a neospravedlnitelných stereotypů“ (Gauntlett, 1998, s. 6).

\section{Problémy mediální výchovy - protekcionismus, normativnost a objektivismus}

Mediální výchova strukturující své cíle, obsah a metody na základě představy obecně poznatelných principů a mechanismů mediálního působení, jehož projevy jsou relativně ustálené, všeobecné a měřitelné, se může do jisté míry opírat pouze o myšlenkový a teoretický konstrukt. Pokud je ovšem kritika metodologie výzkumu mediálních účinků pravdivá a současně platí, že koncept mediálních účinků tvoří strukturní element mediálněpedagogické praxe, pak lze vyvodit, že mediální výchova ze své podstaty tenduje ke třem charakteristikám: protekcionismu, normativnosti a objektivismu.

\subsection{Protekcionismus}

Představa mocných médií významně ovlivňujících člověka a společnost vede $\mathrm{k}$ tendenci chránit děti a mládež před jejich potenciálně nežádoucími účinky. Tato tendence je implicitně motivována (empiricky nepodloženým, viz Kunkel, 2004) přesvědčením, že dospělí jsou vůči mediálním vlivům náchylní méně než děti, protože mají relevantní znalosti o médiích a odpovídající kompetence, kterými děti nedisponují. Jinak řečeno jsou mediálně gramotní. Úlohou rodiče, pedagoga nebo politika je proto poskytnout dítěti vědění a dovednosti nezbytné $\mathrm{k}$ tomu, aby se dokázalo před médii chránit, př́ípadně iniciovat určitá systémová opatření. ${ }^{11}$ Tato opatření je možno na systémové úrovni (např ve škole) iniciovat, jelikož povaha mediálních účinků je předem známa a reakce jednotlivců je předvídatelná.

11 Typu labelingu nebo cenzury. 
Paternalismus a protekcionismus $\mathrm{v}$ mediální výchově má ovšem tendenci ignorovat mediální zkušenost žáků jako irelevantní a nahrazovat ji syntetickou a generalizovanou zkušeností prezentovanou pedagogem. Rezignuje tak na porozumění individuálním formám interakcí dětí s médii a současně jejich individualitu připoutává k potvrzující a schvalující autoritě pedagoga (viz Masterman, 1985).

\subsection{Normativnost}

Ochranitelská tendence poskytuje legitimitu normativní mediálněpedagogické praxi. Pokud má učitel chránit žáky před nežádoucími vlivy médií, musí mu být přiznáno právo rozhodovat o tématech a poznatcích, které se stanou obsahem výuky, o prezentovaných mediálních obsazích a jejich preferovaných interpretacích, o adekvátních postojích a normách chování vůči médiím. ${ }^{12}$ Očekávané vědění a kompetence žáků jsou předem definované, jsou jimi podmíněny výukové cíle, obsah a metody, které současně směřují $\mathrm{k}$ jejich osvojení. To je pak posuzováno a hodnoceno.

Vědění o médiích a mediální kompetence tak nejsou vytvářeny ve vzájemné interakci mezi učitelem, žáky a výukovým objektem, v aktivní a angažované participaci na objektu poznávání. Jsou předem konstituovány v diskurzivních systémech vztahujících se $\mathrm{k}$ médiím a reprodukovány v mediálněpedagogické praxi. Mediální výchova je tak především doménou normativní transmise.

Z jistého pohledu na tom není nic problematického. Vzdělávací praxe zpravidla nevytváří vlastní odborné poznatky, pedagogové nebývají aktivními badateli ve svém oboru. Jejich role je zprostředkovat žákům vědění, které je konstituováno $\mathrm{v}$ jiných vědních oborech, a to způsoby a formami, které umožní adekvátní porozumění. Učitel je primárně didaktickým a metodickým expertem, jehož teoretická příprava směřuje především do oblasti pedagogiky (srov. Maňák, 2011), nikoliv expertem či aktivním badatelem v oboru, jehož koncepty žákům transferuje. ${ }^{13}$

12 Je třeba podotknout, že autonomie učitele je v tomto ohledu limitována závazným rámcovým kurikulem a především opět dominantním odborným diskurzem o médiích, který se promítá do mediálněpedagogické praxe.

13 Nepředpokládá to ostatně ani Standard učitele pro kariérní systém vytvořený Národním institutem pro další vzdělávání. V oblasti 1 Učitel a jeho profesní Já, 1.1.3 Učivo se od učitelů na nejvyšších kariérních stupních (vynikající učitel a pedagogický lídr ve škole a vynikající učitel a lídr ovlivňující vzdělávací systém) vyžaduje pouze to, aby sledovali vývoj svého aprobačního předmětu a svou odbornou znalost směřovali ke zkvalitňování kurikulárních dokumentů (ŠVP, RVP), nikoliv aby se aktivně zapojovali do odborného výzkumu. 
Nicméně to, co může být akceptováno v empirických oborech, nabývá v kontextu mediální výchovy problematických konsekvencí. Mediální komunikace je dynamickým procesem, do něhož vstupuje řada proměnných rozmanité povahy. Zatímco technologický vývoj vymezuje možnosti komunikování, samotná komunikace je především sociálním jednáním. Proces tvorby a recepce mediálních sdělení je determinován společenskou kulturou, hodnotami, sociální i individuální zkušeností, subjektivními cíli a záměry, které jsou jejími jednotlivými aktéry do mediované komunikace promítány. Poznání médií by tedy mělo, kromě rozvoje znalostí a dovedností, vycházet také z reflexe vlastní zkušenosti žáka jako aktéra mediální komunikace.

V normativním modelu mediální výchovy jsou žákům prezentovány předem definované soubory poznatků o médiích, jsou jim představovány předem vybrané mediální obsahy a demonstrovány předem určené formy adekvátních interpretací. Dominantním aktérem výchovně-vzdělávacího procesu je učitel, žáci mají pouze omezené možnosti prezentovat vlastní vzdělávací potřeby a zájmy, rozhodovat o tématech a aktivitách, vnášet do diskuse vlastní zkušenost. Namísto toho by se žáci i učitelé měli stát badateli zkoumajícími nejen objektivní zákonitosti mediální produkce, ale také subjektivní motivy, perspektivy, postoje a procesy vztahující se $\mathrm{k}$ určitému specifickému porozumění realitě, které je kódováno do mediálních textů nebo naopak ovlivňuje jejich čtení. Vzhledem k sociální podstatě mediální komunikace je pojetí mediální výchovy jako platformy transmise předem definovaných souborů vědění pro komplexní poznání sociálního kontextu médií nevyhovující.

\subsection{Objektivismus}

Normativní pedagogická praxe nakonec prezentuje vědění jako bezproblémové, vycházející z objektivního poznání reality. Poznatky jsou žákům předávány jako pravdivé, platné a dané. Nedochází k jejich kritické reflexi umožňující nahlédnout selektivní či subjektivní povahu vědění, jeho sociální či ideologickou podmíněnost. V mediální výchově se tak reprodukuje přesvědčení, že média mohou být chápána a vysvětlována nestranně a ideologicky neutrálně, bez vazby na sociální a mocenský kontext determinující proces produkce a distribuce symbolických významů ve společnosti. ${ }^{14}$ Hrozí tak, že se mediálněpedagogické aktivity zaměří pouze na explicitní projevy médií, aniž by byl brán zřetel na „intelektuální, historický a analytický základ, bez něhož mediální analýzy riskují, že se stanou povrchními, mechanickými nebo bagatelizujícími“ (Ferguson, 1998, s. 2).

14 I to je svým způsobem jistý druh ideologie. 
Kritická analýza mediálních textů vyžaduje angažovaný přístup založený na jasné výchozí perspektivě, ze které na daný text nahlížíme. To umožní uvědomit si, že symbolická komunikace je vždy ideologicky determinovaná, vždy vyjadřuje partikulární perspektivy, které ve veřejném diskurzu soupeří o dominanci. Takové poznání může teprve vést $\mathrm{k}$ nahlédnutí symbolické komunikace jako procesu uplatňování moci, $\mathrm{k}$ plnému porozumění procesům mediované komunikace ve vztahu k širší společenské a mocenské struktuře a také k sebereflexi vlastních komunikačních aktů a jejich sociálních důsledků. Objektivizující př́ístup nevytváří pro tento typ reflexe sociálních praxí vhodné podmínky.

\section{$4 \quad$ Kritické myšlení a mediální výchova}

Uvedené tendence problematizují rozvoj kritického myšlení o médiích jako deklarovaného cíle mediální výchovy. Podle Ennise (2011) zahrnuje obecné kritické myšlení dispozice a schopnosti vyhledávat alternativní vysvětlení a být jim otevřený, zvažovat různé pohledy na věc, být stále dobře informovaný, zaujímat postoje pouze na základě dostupných informací a mimo jiné také být schopen neustále reflektovat svá vlastní přesvědčení. Fairclough (1995, s. 54) specificky v kontextu mediálních diskurzů hovoří o tom, že slovo „kritický“ odkazuje k vědomí, že sociální praktiky obecně a užívání jazyka v sociální praxi provázejí efekty, kterých si nejsme většinou vědomi, a to především ve vztahu k uplatňování moci ve společnosti. Podle McLaughlina a DeVoogda (2004) je kritická gramotnost definována zaměřením na problematiku moci a rozvoj reflexe, transformaci a sociální akci, zaměřením na problém a jeho komplexnost a zkoumáním různých perspektiv (s. 54-55). Zkoumání a odhalování „role jazyka a komunikace v definování vztahů moci a dominance" je klíčovým předpokladem pro rozvoj kritické mediální gramotnosti také podle Kellnera a Sharea (2007). Podle nich by se mediální výchova měla zaměřit na „kritiku ideologie a analyzování politiky reprezentace ve stěžejních dimenzích genderu, rasy, třídy a sexuality" (s. 4), tedy přinášet porozumění roli institucionalizovaného sdělování při uplatňování ideologie, moci a dominance v procesu budování identity v masové společnosti. 
V tomto ohledu přistupují české kurikulární dokumenty k mediální výchově spíše konzervativně. Mediální gramotnost je $\mathrm{v}$ nich definována především jako

schopnost analyzovat nabízená sdělení, posoudit jejich věrohodnost a vyhodnotit jejich komunikační záměr, popřípadě je asociovat s jinými sděleními; dále pak orientaci v mediovaných obsazích a schopnost volby odpovídajícího média jako prostředku pro naplnění nejrůznějších potřeb (RVP ZV, 2017, s. 138),

či jako

soubor poznatků a dovedností, které člověku umožňují nakládat s mediální produkcí, jež se mu nabízí, účelně a poučeně, dovoluje mu média využívat ku svému prospěchu a dává mu nástroje, aby dokázal ty oblasti mediální produkce, které se jím snaží skrytě manipulovat, odhalit. (RVP G, 2007, s. 77)

Oproti tomu dokumenty EU výrazněji akcentují, a jako jeden ze strategických cílů vzdělávacích soustav členských států prosazují, kritickou dimenzi mediální gramotnosti a důležitost rozvoje kritického myšlení pro posílení schopnosti „rozpoznat propagandu a odolat veškerým formám indoktrinace“ v mediálním prostředí či „odolávat všem formám diskriminace“ (European Commission/EACEA/Eurydice, 2016, s. 3).

Takto definované kritické myšlení se výrazněji vztahuje k odhalování mocenských praktik za procesem symbolické výměny. $\mathrm{V}$ českých strategických (Bílá kniha, 2001; Dlouhodobý záměr vzdělávání a rozvoje vzdělávací soustavy ČR na období 2015-2020) a kurikulárních dokumentech (RVP) však přesná definice kritického myšlení chybí, přestože je kritický odstup od médií jedním z deklarovaných cílů mediální výchovy. Vztah médií a moci je pojímán zúženě (předvolební kampaně a jejich význam, viz RVP ZV), spíše historicky (role médií ve společenských změnách, viz RVP ZV, či v „,historicky vypjatých okamžicích", viz RVP G), a v některých případech dokonce stereotypně (média jako "hlídací pes“ či „čtvrtý stav“, viz RVP G, s. 78). Řada témat osvětlujících roli médií v uplatňování moci ve společnosti pak absentuje zcela (role jazyka a sdělování v procesu sociální konstrukce reality, vztah mezi jazykem a mocí, determinace sociálních praxí diskurzivními praxemi, problematika ideologie atd.).

Je otázkou, nakolik může takto vymezený koncept mediální výchovy skutečně rozvíjet kritické myšlení o médiích a o společnosti. Chceme-li v žácích rozvíjet kriticky angažované jedince, kteří sami sebe vnímají jako autonomní 
aktéry medializované komunikace a prostřednictvím porozumění médiím rozumějí sobě a světu, neměla by mediální výchova zůstat pouze u reflexe médií, ale měla by se zaměřit na celospolečenský kontext, $\mathrm{v}$ němž média působí. Má-li být mediální gramotnost platformou pro rozvoj kritického myšlení, je nemožné zůstat striktně v hranicích kurikula nastaveného mediální problematikou, ale je třeba učit žáky vidět za média samotná a kriticky reflektovat sociální praxe, jichž jsou média součástí.

V takovém případě bychom měli žáky učit tázat se nejen po povaze mediálních sdělení, ale obecně po povaze a mechanismech tvorby a distribuce vědění ve společnosti prostřednictvím symbolické produkce v médiích, ve vědě či vzdělávání. Měli bychom je vést k porozumění vztahu sociálních institucí produkujících určité významy k ustavení, legitimizaci a reprodukci společenských struktur moci (viz výše Kellner \& Share, 2007). Kriticky kompetentní žák by měl umět zpochybňovat nejen zdánlivou samozřejmost mediálních sdělení, ale celé sociální a institucionální struktury společnosti: politiky, ekonomiky, vzdělávání a symbolických obsahů, které produkují.

\section{Rekonceptualizace mediálněpedagogické praxe}

Protekcionistická, normativní a objektivistická mediálněpedagogická praxe neumožňuje rozvoj kritického sebevědomí žáka jako mediálního aktéra, nestimuluje rozvoj individuálního chápání médií a sebe sama v procesu mediální komunikace. Zkušenost žáků s médii je tvarována a usměrňována podle předem daných kritérií, chápání médií a reakce na ně jsou výukou o médiích sjednocovány a usměrňovány ve prospěch internalizace „obecně platných“ poznatků o médiích a „správných“ postojů k nim.

Normativní prezentace vědění jako objektivních faktů (o kterých se mezi učitelem a žáky nediskutuje) vede $\mathrm{k}$ jejímu bezproblémovému akceptování ze strany žáků a znemožňuje nahlédnout sociální a mocenskou podstatu vědění (viz Foucault, 1984), která je podmínkou kritické reflexe mediálně reprezentovaných výpovědí o sociální realitě. $V$ normativně orientované a na předem definovaném souboru relevantních „faktů“ založené mediální výchově je př́itomné riziko, že žáci získají pouze „krátkodobé, dekontextualizované znalosti“ a nerozvinou porozumění médiím v kontextu jejich každodenního užívání (viz Hobbs, 2011). Absence sociálního, politického a ekonomického kontextu v kritické reflexi médií vede přinejlepším ke zjednodušené představě, která je neadekvátní složitosti problematiky (viz Livingstone, 1996). Za těchto 
podmínek se žáci nestávají svébytnými aktéry mediální komunikace, nejsou ve vztahu k médiím ani ke společnosti „kriticky autonomní“ (viz Masterman, 1985). Jejich chápání médií a obecně sociálních jevů je závislé na hodnocení a potvrzení ze strany individuálních či institucionálních autorit, rodiče nebo učitele (případně veřejného mínění obecně), které jim poskytne relevanci. Mediální výchova se pak nestává nástrojem rozvoje kritické autonomie, ale ve skutečnosti myšlení žáků usměrňuje do předem vymezených kognitivních schémat.

S ohledem na tyto problémy je zapotřebí znovu promyslet základní východiska a teoretickou orientaci mediální výchovy. Je třeba položit si otázku, zda orientace na sociálněvědní paradigma $\mathrm{v}$ mediálních studiích a na koncept účinků médií vytváří fundamentální základy pro rozvoj kritického myšlení o médiích a společnosti. Jak uvádějí Robertson a Scheidler-Berns (2016, s. 2247): „Dovednosti kritické mediální gramotnosti byly historicky definovány v nekritickém směru." Jako jeden z důvodů uvádějí „pozornost k nebezpečím způsobeným (pře)vystavením médiím", tedy orientaci mediálního výzkumu i mediální pedagogiky na problematiku účinků médií. Namísto toho akcentují, že kritická mediální gramotnost mimo jiné „podporuje uvědomění, že různí jednotlivci vnímají nebo rozumějí stejným médiím různě“ (s. 2249). Jinak řečeno, vliv médií je na různé jedince v různých situacích vždy různý. Právě tato pluralita vnímání a interpretace mediálních sdělení problematizuje normativní koncepty mediálních účinků.

Pokud má mediální výchova rozvíjet kritické myšlení o médiích, pak by se měla vzdát představy o objektivním poznání, které může být pouze zprostředkováno (viz také Giroux, 2011), a hledat cesty, jak budovat porozumění mediální problematice prostřednictvím vlastní zkušenosti žáků s médii, která je rozmanitá a vysoce individuální. Vědění o médích musí zahrnovat jak dimenzi zprostředkovaných faktů, tak dimenzi vlastní recepce médií, reflexe vlastního prožívání, cítění a jednání v interakci s mediálními produkty. Stejně tak musí zohledňovat politický, ekonomický a kulturní kontext tvorby a distribuce vědění $v$ médiích a $v$ sociálních institucích obecně (včetně vzdělávání). Znalost těchto kontextů je předpokladem porozumění sociální podstatě vědění a symbolické komunikace. Poskytne vědění relevanci pro praktický život, umožní zasadit vnímané jevy do širšího společenského rámce, pomưže porozumět mechanismům vlastního myšlení a prožívání a umožní transformovat problematické sociální praxe. 
Objektivistické a normativní hledisko vytvářející etablovaný školní diskurz nepropojuje vzdělávací obsah mediální výchovy s individuální zkušeností žáků s médii a brání rozvoji skutečné kritické mediální gramotnosti, která by směřovala k reflexi sociálních praxí za médii a vztahovala se ke světu mimo školu. Robertson a Scheidler-Berns (2016) doporučují propojit gramotnost rozvíjenou ve škole s gramotností, kterou si žáci a studenti budují ve světě mimo školu (tzn. individuální rozumění médiím a světu). To ovšem mimo jiné znamená zásadně rozvolnit kurikulum, upustit od tendence vnímat mediální výchovu jako platformu pro přenos poznatků o médiích a poskytnout žákům prostor, aby vzdělávací obsah a témata sami definovali na základě svých zkušeností, zájmů a potřeb a především, aby získali příležitost pro dialog o individuálním vnímání médií.

Změnu perspektivy může do mediální výchovy přinést odpoutání se od sociálněvědního paradigmatu ve prospěch interpretativní (kulturální) a kritické analýzy. Zatímco kritické př́stupy akcentují politicko-ekonomickou rovinu symbolické komunikace a umožňují nahlédnout širší sociální a mocenský kontext tvorby a distribuce vědění ve společnosti, kulturální tradice obrací pozornost k člověku jako autonomnímu aktéru mediální komunikace: producentu nebo př́ijemci mediálních sdělení. Přestože ve vztahu k mediálním účinkům může kritická tradice $v$ některých případech vystupovat normativně (viz Buckingham, 1993), pro kulturální přístup jsou média fenoménem mnohem variabilnějším a nepředvídatelnějším, jemuž je možné správně porozumět pouze tehdy, porozumíme-li lidem, kteří média užívají. Oba přístupy pak chápou média jako integrální součást širšího systému institucionálních a kulturních praktik.

Kritická a kulturální tradice poskytují hlubší porozumění procesům upevňování sociálního řádu prostřednictvím tvorby a distribuce symbolických a kulturních produktů. Orientují analytickou pozornost na odhalování implicitních předpokladů, partikulárních přesvědčení a hodnotových soudů podepírajících obecně sociální praxe a skupinové i individuální formy reakcí na ně. Umožňují tak komplexněji formovat kritické myšlení o společnosti jako takové, o původu, podobách a technikách udržování sociálních norem prostřednictvím symbolické produkce, její historické determinovanosti a o reálném společenském dopadu na ty, kteří jsou z různých (třídních, náboženských, rasových, etnických nebo politických) důvodů z dominantní společenské struktury vylučováni. Takové myšlení je transformativní, je připravené k angažované akci vedoucí k odstranění opresivních sociálních praxí. 


\subsection{Mediální výchova jako konstruktivistická pedagogika}

Mediální výchova usilující o rozvoj osobnosti kriticky reflektující procesy celospolečenské symbolické produkce si nemůže vystačit s pouhým transferem poznatků z jiných oborů do mediálněpedagogické praxe. Naopak je důležité, aby bylo poznání o médiích a společnosti konstruováno společně s žáky. Prostřednictvím vytváření situací, ve kterých je umožněno nahlédnout obecnější sociální procesy produkce a distribuce významů ve společnosti a současně reflektovat sama sebe jako jejich aktéra, může dojít ke komplexnímu porozumění médiím a sociálnímu významu jejich užívání. Poznatky vztahující se $\mathrm{k}$ médiím je třeba konstruovat $\mathrm{v}$ př́mém kontaktu s médii, nikoliv pouze předávat hotové sumy vědění. Kritické myšlení vyžaduje angažovanost na objektu poznání, ${ }^{15}$ nelze ho formovat prostřednictvím osvojení si určité sumy předem vytvořených poznatků, technik nebo sledu operací, ale je třeba vycházet z přirozené zkušenosti dětí, reflektovat ji a proměňovat v transformativní praxi.

Mediální výchova by tedy měla být autonomní disciplínou alespoň v tom smyslu, že doplňuje a obohacuje zprostředkovaná fakta o jejich kritickou reflexi a také o individuální zkušenost, která umožní jejich zahrnutí do určitého kognitivního rámce, a tedy i jejich hlubší porozumění. Koncept předem definovatelných, rozpoznatelných a měřitelných mediálních účinků organizovaných sumou relativně ustálených procesů a zákonitostí, který přímo stimuluje protekcionistickou, normativní a objektivistickou mediálněpedagogickou praxi, by mohl být nahrazen takovým pojetím médií, které akcentuje pluralitu, vzájemnou provázanost a nepředvídatelnost interakcí člověka s médii, institucemi i ostatními jedinci a společností. Takový koncept by nevedl $\mathrm{k}$ formulování obecně platných teorií mediálních účinků, ale orientoval by pozornost k člověku jako mediálnímu aktéru a ke zkoumání celého sociálního kontextu médií. To by pro mediální výchovu znamenalo nejen nezávislost na dominantních konceptech mediálních studií, ale především autonomii při vytváření vlastního poznatkového aparátu a při formulaci výukových cílů, obsahu a metod.

Z hlediska potenciálu mediální výchovy rozvíjet kritickou autonomii žáků se to zdá být nezbytné. Je žádoucí, aby mediální výchova nepřistupovala k problematice „odzadu“ (viz výše Gauntlett, 1998) a nekonstruovala otázky a problémy na základě již hotových idejí. Mediální výchova může místo toho

15 Viz Deweyho pragmatická pedagogika. 
založit svůj teoretický rámec na zkoumání forem a podob interakce jednotlivců s médii. Namísto hledání odpovědi na otázku, co média dělají s lidmi, se může ptát, co dělají lidi s médii. Jaké jsou záměry producentů mediálních sdělení (at' už těch profesionálních, nebo samotných žáků)? Jaké zájmy sledují a jaké taktiky a strategie používají? A jak média skutečně vnímají jejich recipienti, jak jejich významy interpretují? Porozumět reálným účinkům médií je možné teprve prostřednictvím zkoumání člověka v běžné každodenní interakci s nimi.

Jako pedagogická disciplína má k tomu mediální výchova velmi dobrou pozici. Funguje zde dynamika malých sociálních skupin: žáci jsou ve vzájemném intenzivním a dlouhodobém kontaktu, tvoří uzavřenou skupinu, v jejímž rámci se rozvíjejí skupinové vztahy. Je tak možné bezprostředně zkoumat vliv sociálních skupin na individuální chápání médií u jednotlivců. Dlouhodobá přítomnost členů skupiny pak umožňuje dlouhodobé pozorování individuálních i skupinových interakcí s médii a jejich proměn v čase. Př́tomnost učitele umožňuje zkoumat vliv sociální autority na postoje žáků k médiím a nakonec tvorba médií, je-li jí poskytnuta potřebná míra autonomie, umožní pochopit, proč a za jakým účelem žáci média vytvářejí a užívají.

\section{Závěr}

Mediální výchova by se měla dokázat oprostit od závislosti na dominantních perspektivách produkovaných mediálními studii a začít budovat autonomní poznatkový aparát, postavený na kvalitativním výzkumu organizovaném v rámci vlastní pedagogické praxe. To neznamená odmítnout stávající teorie médií nebo koncept mediálních účinků jako takový, ale ověřit jejich relevanci ve výchovně-vzdělávacím procesu. Mediální výchova má veškeré potenciály stát se autonomním výzkumným polem, které může doplnit poznatky mediálních studií o kvalitativní výzkumnou reflexi každodenní mediální zkušenosti lidí a porozumění tomu, $\mathrm{k}$ čemu lidé média používají a s jakým záměrem (viz Kahn, 2007).

Současně může na této perspektivě vystavět základy vlastní praxe. Taková mediální výchova nebude normativně-transmisivní povahy, ale bude autonomně konstituovat svoji podobu na základě poznatků generovaných vlastní praxí: podnětů, které přinášejí sami její aktéři, učitelé i studenti. Bude vstřrícnější ke vzdělávacím potřebám žáků a flexibilní z hlediska cílů, obsahu a metod. Bude směřovat mediálně-pedagogické aktivity ke komplexnějšímu 
porozumění médiím a k sociálnímu kontextu jejich užívání. Může se tak stát plnohodnotným partnerem mediálních studií, který vnese do výzkumu médií poznatky nabyté $v$ mediálně-pedagogické praxi a současně mu poskytne pedagogickou relevanci. Mezi mediálními studii a mediální výchovou tak nadále nemusí panovat vztah teoretické závislosti, ale vzájemně se obohacující kooperace při zkoumání fenoménu médií a mediální komunikace ve společnosti a při rozvoji mediálně gramotného člověka.

\section{Literatura}

Anderson, J. (1980). The teoretical lineage of critical viewing curricula. Journal of Communication, 30(3), 64-70.

Barker, M., \& Petley, J. (2001). Ill effects: The media/violence debate. London: Routledge.

Bílá kniha. Národní program rozvoje vzdělávání v České republice. (2001). Praha: MŠMT. Dostupné z http://www.msmt.cz/dokumenty/bila-kniha-narodni-program-rozvoje-vzdelavani-v-ceske-republice-formuje-vladni-strategii-v-oblasti-vzdelavani-strategie-odrazi-celospolecenske-zajmy-a-dava-konkretni-podnety-k-praci-skol

Buckingham, D. (1993). Changing literacies: Media education and modern culture. London: Tufnell Press.

Dlouhodobý záměr vzdělávání a rozvoje vzdělávací soustavy ČR na období 2015-2020. Praha: MŠMT. Dostupné z http://www.msmt.cz/vzdelavani/skolstvi-v-cr/dlouhodoby-zamervzdelavani-a-rozvoje-vzdelavaci-soustavy-3

Doporučené očekávané výstupy: Metodická podpora pro výuku průřezových témat na základních školách. (2011). Praha: Výzkumný ústav pedagogický v Praze. Dostupné z http://digifolio. rvp.cz/artefact/file/download.php?file=28981\&view=3951

Ennis, H. R. (2001). The nature of critical thinking: An outline of critical thinking dispositions and abilities. Inquiry: Critical Thinking Across the Disciplines, 26(1), 4-18.

European Commission/EACEA/Eurydice (2016). Promoting citizenship and the common values of freedom, tolerance and non-discrimination through education: Overview of education policy developments in Europe following the Paris Declaration of 17 March 2015. Luxembourg: Publications Office of the European Union.

Fairclough, N. (1995). Media discourse. London: Arnold.

Ferguson, R. (1998). Representing 'race': Ideology, identity and the media. New York: Oxford University Press.

Fink, E. J., \& Gantz, W. (1996). A content analysis of three mass communication research traditions: Social science, interpretative studies, and critical analysis. Journalism \& Mass Communication Quuarterly, 73(1), 114-134.

Foucault, M. (1984). Truth and power. In P. Rabinow (Ed.), The Foucault reader (s. 51-75). New York: Pantheon Books.

Foucault, M. (2002). Archeologie vědění. Praha: Herrmann a synové.

Fourie, P. J. (2007). Media studies. Institutions, theories and issues. Lansdowne: Juta.

Gauntlett, D. (1998). Ten things wrong with the media effects model. In R. Dickinson, R. Harindranath, \& O. Linné (Eds.), Approaches to audiences - A reader (s. 120-130). London: Arnold. 
Giroux, H. A. (2011). On critical pedagogy. New York: Bloomsbury Academic.

Hobbs, R. (2011). The state of media literacy: A response to Potter. Journal of Broadcasting \& Electronic Media, 55(3), 419-430.

Jirák, J. (2006). Proč potrebujeme mediální výchovu. RVP.cz. Dostupné z http://clanky.rvp.cz/ clanek/c/z/540/proc-potrebujeme-medialni-vychovu.html/?oblibene=1

Jirák, J., \& Köpplová, B. (2003). Média a společnost. Praha: Portál.

Kahn, R. (2007). Research into critical media pedagogy as cultural study. In B. Kozuh, A. Kozlowska, \& P. Krope (Eds.), Description and explanation in educational and social research. Warsaw: Rodn "WOM" Publishers. Dostupné z http://www.academia.edu/167217/Research_into_ Critical_Media_Pedagogy_as_a_Cultural_Study.

Kellner, D., \& Share, J. (2007). Critical media literacy is not an option. Learning Inquiry, 1(1), 59-69.

Kline, S. (2003). Media effects: Redux or reductive? Participations: International Journal of Audience Research, 1(1).

Kunkel, D., Wilcox, B., Cantor, J., Palmer, E., Linn, S., \& Dowrick, P. (2004). Report of the APA task force on advertising and children. Dostupné z https://www.apa.org/pi/families/resources/ advertising-children.pdf.

Livingstone, S. (1996). On the continuing problem of media effects research. In J. Curran \& M. Gurevitch (Eds.), Mass media and society (s. 305-324). London: Edward Arnold.

Lowery, S., \& M. L. DeFleur (1995). Milestones in mass communication research: Media effects. New York: Longman.

Maňák, J. (2011). K problému teorie a praxe v pedagogice. Pedagogická orientace, 21(3), 257-271.

Masterman, L. (1985). Teaching the media. London: Comedia Pub. Group.

McGuire, J. W. (1986). The myth of massive media impact: Savaging and salvagings. In G. Comstock (Ed.), Public communication and behavior (s. 173-257). New York: Academic Press.

Mclaughlin, M., \& DeVoogd, G. (2004). Critical literacy as comprehension: Expanding reader response. Journal of Adolescent \& Adult Literacy, 48(1), 52-62.

McQuail, D. (1987). Mass communication theory: An introduction. London: Sage.

McQuail, D. (1999). Úvod do teorie masové komunikace. Praha: Portál.

Napoli, M. P. (2014). Measuring media impact: An overwiev of the field. New Brunswick: Rutgers University Press.

Nečas, V., \& Trampota, T. (2008). Vývoj zkoumání účinků médií. Dostupné z http://www.socioweb. cz/index.php@disp=temata\&shw=302\&lst=107.html.

O’Neill, B. (2011). Media effects in context. In V. Nightingale (Ed.), The handbook of media audiences (s. 320-340). Oxford: Blackwell.

O'Sullivan, T., Hartley, J., Saunders, D., Montgomery, M., \& Fiske, J. (2006). Key concepts in communication and cultural studies. London: Routledge.

Perse, E. M. (2001). Media effects and society. London: Lawrence Erlbaum Associates Publishers.

Piette, J., \& Giroux, L. (1996). The theoretical foundations of media education programs. In R. Kubey (Ed.), Media literacy in the information age (s. 89-134). New Brunswick: Transaction.

Potter, W. J. (2010). The state of media literacy. Journal of Broadcasting \& Electronic Media, 54(4), 675-696. 
Potter, W. J., Cooper, R., \& Dupagne, M. (1993). The three paradigms of mass media research in mainstream journals. Communication Theory, 3(4), 317-335.

Rámcový vzdělávací program pro základní vzdělávání. (2007). Dostupné z http://www.vuppraha. cz/wp-content/uploads/2009/12/RVPZV_2007-07.pdf

Robertson, L., \& Scheidler-Benns, J. (2016). Critical media literacy as a transformative pedagogy. Literacy Information and Computer Education Journal, 7(1), 2247-2253.

Sholle, D. (1994). The theory of critical media pedagogy. Journal of Communication Inquiry, 18(2), 8-29.

Schramm, W., Lyle, J., \& Parker, E. B. (1961). Television in the lives of our children. Stanford: Stanford University Press.

Storey, J. (2008). Cultural studies and the study of popular culture $\left(5^{\text {th }}\right.$ edition). London: Routledge.

Valenta, P. (2016). Kritická mediální pedagogika: teoretická východiska a prrínos pro mediální výchovu. (Disertační práce). Praha: Univerzita Karlova, Filozofická fakulta, katedra pedagogiky.

Williams, R. (1975). Television: Technology and cultural form. New York: Schocken Books.

Wimmer, D. R., \& Dominick, J. R. (2010). Mass media research: An introduction. Boston: Wadsworth Publishing.

\title{
Autor
}

Mgr. Petr Valenta, Ph.D., Univerzita Karlova, Filozofická fakulta, Katedra pedagogiky, Celetná 20, 11638 Praha 1, e-mail: val.petr@seznam.cz

\section{The theoretical underpinnings as a determinant of media education praxis}

\begin{abstract}
The theoretical study outlines the structural problems of media education derived from its theoretical dependence on media studies and social science paradigm of media effects research. The introductory chapters present media education within the theoretical field of media studies. It is argued that media education has not its own theory but derives its knowledge, educational objectives, curriculum and methods, from the dominant concepts generated within the field of media studies. The concept of media effects is identified as the structural element of its praxis. The prevalence of social science approach in research of media effects leads to the formation of the concept of media effects, which can be simply observed, described and generalized. However, this approach does not fully grasp the problems of media in their broad social and cultural context and leads to the establishment of media education, which is protectionist, normative and objectivist in nature. Finally an alternative critical approach allowing to structure media education as an autonomous research and pedagogical field is offered. Media education can adopt many forms in dependency on the reference theoretical concepts. The dominant media education model, oriented on the social science paradigm of media effect research, can be enriched with other
\end{abstract}


perspectives that enable a comprehensive understanding of media in their social context and lead to the critical reflection of, not only media, but the general social and power praxis. Such a media education would contribute to the effective development of critically thinking participants of media communication. Rethinking the very theoretical background and objectives of media education and emancipating it from the theoretical dependency on social science determined media effects conception seems to be necessary. Integration of interpretative and critical approaches will better support the development of critical media literacy and enable media education to build its own knowledge base and autonomously organize its own teaching praxis.

Keywords: media education, media studies, social science paradigm, media effects, protectionism, normativity, objectivism, critical media literacy

Slavík, J., Janík, T., Najvar, P., \& Knecht, P. (2017). Transdisciplinární didaktika: o učitelském sdílení znalostí a zvyšování kvality výuky napřič obory. Brno: MU.

Kniha se zabývá výzkumem výuky a její kvality se zaměřením na problematiku vztahů mezi teorií a praxí ve vzdělávání s ohledem na profesní přípravu učitelů. V prvních kapitolách jsou osvětlovány filozofické a teoretické předpoklady metodologie výzkumu zaměřeného nejenom na analýzu tvorby učebního prostředí ve výuce, ale také na hodnocení její kvality. Další část je věnována objasnění metodiky $3 \mathrm{~A}$ - výzkumného přístupu speciálně určeného ke zkoumání kvality výuky. V poslední části knihy jsou uvedeny výsledky výzkumu metodikou vícepřípadové studie v pojetí metodiky 3A. Kniha je adresována obecným a oborovým didaktikům, učitelům se zájmem o kvalitu výuky, ředitelům škol a všem pracovníkům, jejich úkolem je hodnotit didaktickou kvalitu výuky.

Pivarč, J. (2017). Poznatky o žákovských prekoncepcích mentálního postižení v kontextu proměny paradigmatu současného vzdělávání. Praha: Karolinum.

Odborná monografie je koncipována jako teoreticko-výzkumná studie, která se zabývá dosud marginálně řešenou tematikou prekoncepcí intaktních žáků o mentálním postižení. Vedle nejnovějších teoretických poznatků o prekoncepcích a konceptu integrace/inkluze jsou v publikaci představeny také komplexní výsledky toho, jak intaktní žáci z běžných základních škol ve věku 10-15 let nahlíží na jedince s mentálním postižením, především je pak poukázáno na jejich představy, znalosti a postoje. Kniha je de facto prvním uceleným monografickým přehledem na toto téma v České republice. Monografie je také zajímavým a významným př́íspěvkem pro teorii a výzkum v oblasti inkluzivního vzdělávání a zejména edukace žáků, kteří se ocitají ve stále ještě „normativně pojatém“ systému českého školství na okraji zájmu nebo zcela vyloučeni z hlavního proudu vzdělávání. 